\title{
RARE-EARTH ELEMENTS IN PRECAMBRIAN IRON FORMATIONS IN VÄYRYLÄNKYLÄ, SOUTH PUOLANKA AREA, FINLAND
}

\author{
KaUko LaAjoki
}

\begin{abstract}
LAAJоKI, KaUKo 1975: Rare-earth elements in Precambrian iron formations in Väyrylänkylä, South Puolanka area, Finland. Bull. Geol. Soc. Finland 47, 93-107.
\end{abstract}

Partial rare-earth element (REE) and ore analyses of 19 samples of oxide-, carbonate-, silicate-, and sulphide-facies rocks from the Superior-type Precambrian (Karelian) iron formations and associated rocks (pelitic metasediments, dolomite, basic tuffite and metadiabase) are given. For comparison one analysis of an Archean (Prekarelidic) iron formation of the Algoma type is also included.

The Karelian iron formations are relatively rich in REE and their REE distribution patterns show depletion of $\mathrm{Ce}$. This is due to the regularly occurring apatite, in which these features are multiplied as is indicated by the analysis of the apatite-rich band. This stratum is interpreted as a marine phosphorite interband and, consequently, the apatite in the iron formations as of marine origin.

With the exception of $\mathrm{Ce}$, the REE distribution patterns in iron formations and associated pelitic metasediments and dolomite are relatively similar. All these rocks show a clear trend towards relative depletion of the lighter REE and $\mathrm{Yb}$ and $\mathrm{Lu}$ in comparison with the North American shale (NAS). Metadiabase and basic tuffite are poor in REE and depleted in the lighter REE in the same way as are tholeitic basalts.

Archean iron formations seem to have a greater Eu:Sm ratio than the younger iron formations. More REE data from geologically wellknown iron formations are needed, however, before any definitive conclusions can be drawn.

Kauko Laajoki, Geological Survey of Finland, SF-02150 Espoo 15, Finland.

\section{Introduction}

Few studies have been published concerning rare-earth element (REE) distribution in iron formations. Classical works in this respect are those of Landergren $(1936,1948)$ from Sweden. From the Soviet Union REE data are available from the Imandra region (Balashov \& Goryainov 1966) and from Krivoy Rog (Tugarinov et al. 1973). Wildeman and Haskin (1973) have given two REE analyses of American iron formations. There are two comprenhensive studies from Canada, which cover REE distribution in Algoma- (Fryer 1971 a) and Superior-type iron 


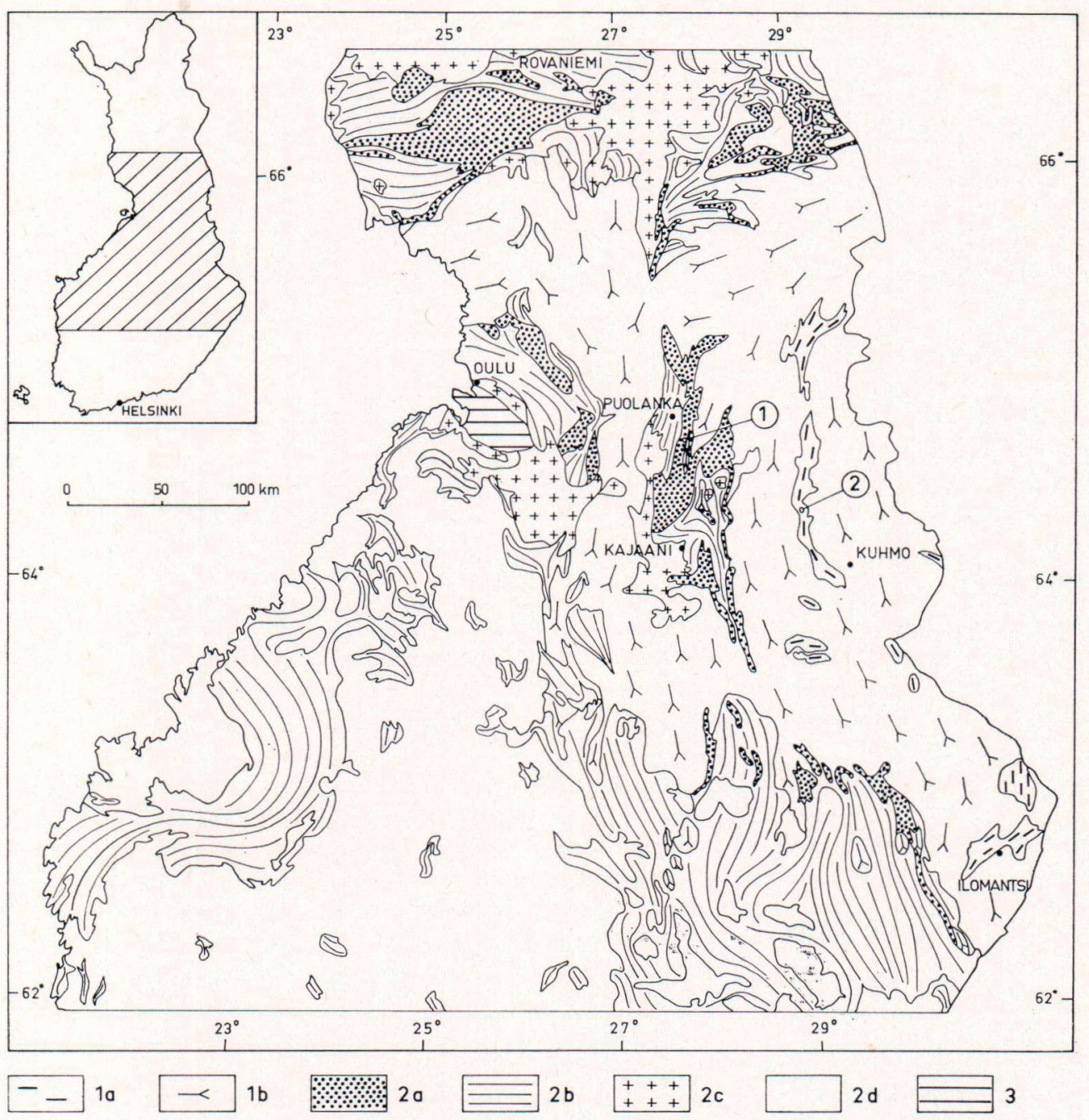

Fig. 1. The sites of the Väyrylänkylä iron formations (1) in Puolanka and the Härmänjoki iron formation (2) in Kuhmo presented on the simplified geological map of Finland (Simonen 1960). 1) Prekarelidic basement: a) schists and paragneisses, b) orthogneisses (granite gneiss). 2) Karelidic and Svecofennidic rocks: a) Karelian (Jatulian) quartzites, b) Karelidic and Svecofennidic schists, gneisses, migmatites, metabasalts and amphibolites, c) Karelidic granite, d) other (mainly silica-rich) orogenic plutonic rocks. 3) Jotnian sedimentary rocks (siltstone). The Kainuan schist belt consists of Karelian quartzites and schists trending from Kajaani to Puolanka.

formations (Fryer 1971 b). Partly on the basis of REE distribution Parák (1973 a, b) has recently proposed that the Kiruna ores are of exhalative-sedimentary origin.

In 1973 the Geological Survey of Finland carried out prospecting on the small ironformation occurrences in Väyrylänkylä, South
Puolanka area, NE Finland (Fig. 1), during which the REE distribution in the iron formations and associated rocks was studied. The purpose of this paper is to give the REE data and to discuss their stratigraphical and genetical significance. The paper constitutes the first part of the author's studies of Finnish iron formations. 


\section{Experimental}

The REE analyses were performed by Mrs. Riitta Zilliacus, M.Sc., in the Reactor Laboratory of the Technical Research Center of Finland. The instrumental activation technique used has been described in other publications (Rosenberg \& Wiik 1971; Rosenberg 1972; Koljonen \& Rosenberg 1974). The other elements given in Table 2 were analysed in the Ore Laboratory of the Geological Survey of Finland using routine oreanalysis methods.

\section{General geological setting}

The study area belongs to the part of the Karelidic belt known as the Kainuan schist belt (Fig. 1). This NNW trending schist belt is characterized by the Jatulian at its eastern margin and by the Kalevian in its middle and western parts. The Jatulian is an epicontinental lithosome composed mainly of quartzites with minor basal arkosites. The Kalevian is a flysch lithosome with phyllites and mica schists. Between these two units a minor lithosome occurs that is known as the Marine Jatulian, and which contains phyllites, black schists, dolomites, quartzites and iron formations. Thus, the iron formations in Kainuu are of the Superior type. Karelidic rocks are intruded by metadiabases of the early Karelidic magmatism and by Karelidic granite.

The general geology of the South Puolanka area has recently been studied by the author (Laajoki 1973). In Väyrylänkylä the iron formations occur in the synclinorium known as the Salmijärvi basin and are met with in the DolomitePhyllite Formation of the Marine Jatulian. The geological setting of the two main iron formations, Pääkkö and Iso Vuorijärvi, is shown in Fig. 2. The stratigraphy and the facies changes within the iron formations in different sections of the Salmijärvi basin are given in Fig. 3 . The eastern parts of the iron-formation horizon (Pääkkö section) consist of silicate-bearing quartz-magnetite-banded rock of the oxide facies. Quartz-siderite-banded rocks of the carbonate facies together with quartz-magnetitebanded rocks and iron-rich black schists of the sulphide facies are encountered in the middle parts (Iso Vuorijärvi section). The two northernmost occurrences of the Iso Vuorijärvi iron formation are mainly composed of iron-silicatemagnetite rock of the silicate facies. In the westernmost parts, about $3 \mathrm{~km}$ west of the Pääkkö farm (outside the map area in Fig. 2), iron-rich black schists of the sulphide facies are predominant (Seppola section). The latter rocks are manganiferous. They are considered to represent the iron formation deposited in the deepest parts of the Salmijärvi basin. The oxide and carbonate facies seem to have deposited in a subtidal environment. Some $5 \mathrm{~km}$ south of the Pääkkö section, in the Körölä area, small iron formations occur that consist mainly of quartz-magnetite-banded rocks.

The whole rock $\mathrm{Pb}-\mathrm{Pb}$ isochrone age of the Pääkkö iron formation is $2080 \pm 45 \mathrm{Ma}$ (Sakko \& Laajoki 1975).

Owing to their small dimensions and poor grade $\left(\mathrm{Fe}_{\text {tot }} \sim 26 \%\right.$ ) the iron formations in Väyrylänkylä are uneconomic. Another detrimental factor is their exceptionally high $\mathrm{P}$ content $(\mathrm{P} \sim 1.2 \%$ ) (Geological Survey of Finland 1974) The partial ore analyses of the ironformation samples (Table 1) dealt with in this study are given in Table 2 .

\section{Sample description}

The names, rock-stratigraphic units and codes of the samples analysed are tabulated in Table 1. The locations of the core samples collected from the map area in Fig. 2 can be determined with the aid of the drill hole numbers and depth intervals included in the sample codes. Samples Nos. $1-5$ represent the dominant rock, quartzmagnetite-banded rock of the oxide facies, from different iron formations in Väyrylänkylä. In 


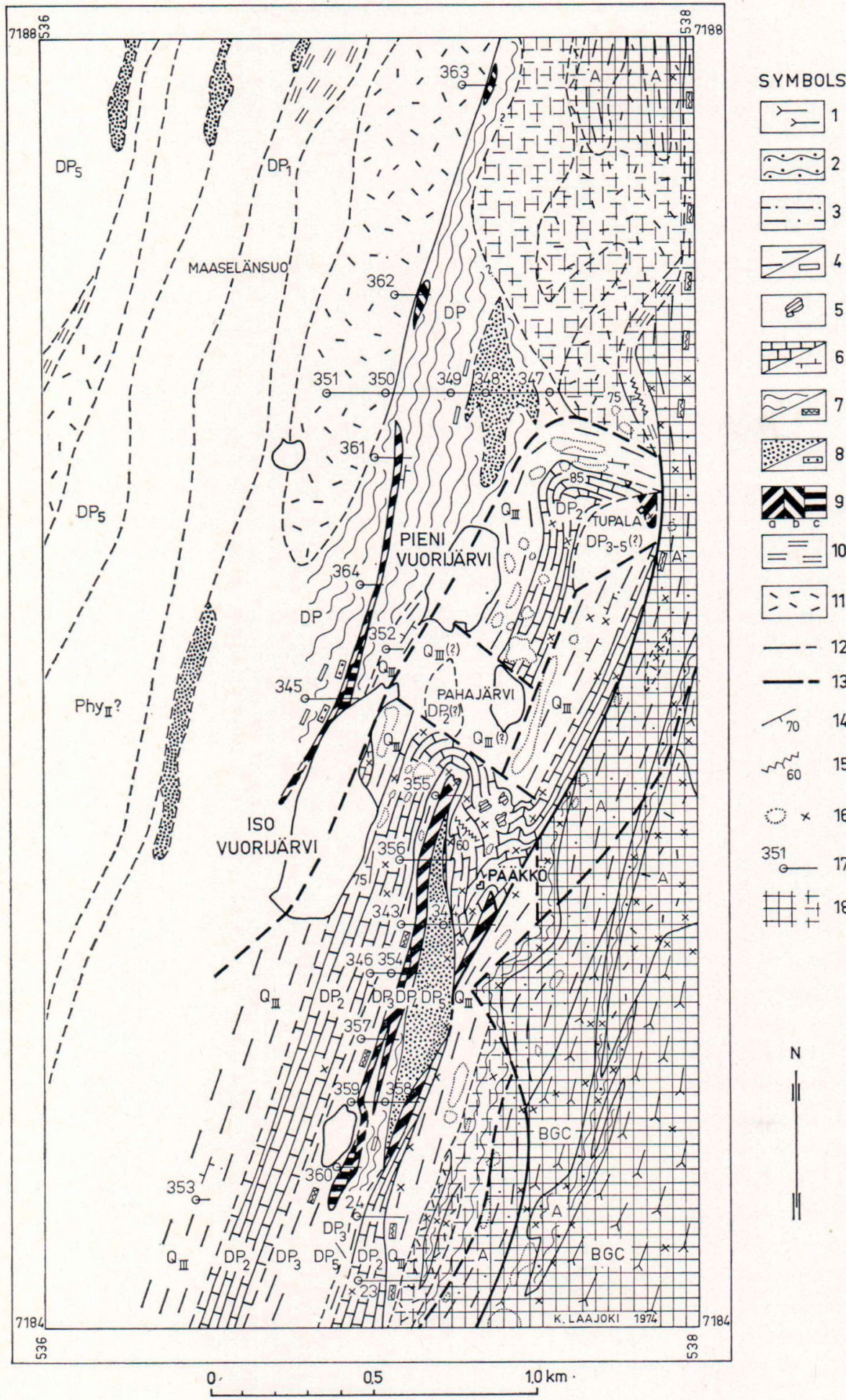

Fig. 2. Stratigraphic-lithologic map of the surroundings of the Pääkkö iron formation (in the middle lower part) and the Iso Vuorijärvi iron formation (in the middle). Lithologic symbols: 1) Prekarelidic basement gneiss.2) Conglomeratic mica schist. 3) Arkosite and feldspar-and/or sericite-bearing quartzite. 4) Quartzite-orthoquartzite/the same as intercalations. 5) Tectonic inclusions of quartzite.6)Dolomite

15 /the same as intercalations. 7) Phyllite/the same as intercalations. 8) Black schist/the same as intercalations. 9)Iron formation: a) oxide facies,

o 17 b) silicate facies, c) carbonate facies. 10) Basic tuffite.

11) Metadiabase and/or -volcanics. 12) Stratigraphic-lithologic contact. 13) Fault or tectonic contact. 14) Bedding and dip. 15) Approximate strike and dip of shear-folded beds. 16) Outcrop. 17) Drill hole and number. 18) Allochthonous formations. Stratigraphic units: BGC) Basement Gneiss Complex. A) Arkosite Formation. QIII) Quartzite Formation III. DP) Dolomite-Phyllite Formation: $\mathrm{DP}_{1}$ ) Seppola Tuffite Member. $\mathrm{DP}_{2}$ ) Salmijärvi Dolomite Member. $\mathrm{DP}_{3}$ ) Pääkkö Quartzite Member. $\left.\mathrm{DP}_{4}\right)$ Pääkkö Iron-Formation Member. $\mathrm{DP}_{5}$ ) Salmijärvi Phyllite Member. Phy ${ }_{\text {III }}$ ) Phyllite Formation II. 
TABLE 1

Rock-stratigraphic positions and codes of the samples of the iron formations and associated rocks. The rock-stratigraphic abbreviations refer to Figs. 2 and 3 . In sample codes the number of the REE-analysis and the map sheet are given first. These are followed by the number of the drill hole and the depth interval of the core samples analysed or the observation number of the outcrop samples (Nos. 18 and 20)

\begin{tabular}{|c|c|c|}
\hline Sample number and name & Rock-stratigraphic unit & Sample code \\
\hline 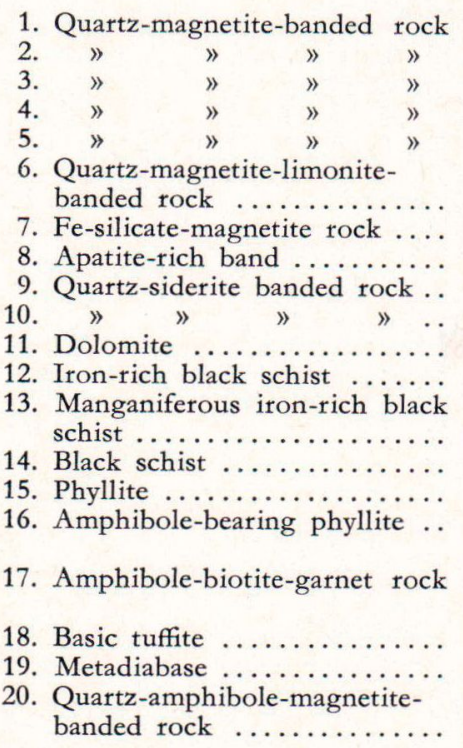 & 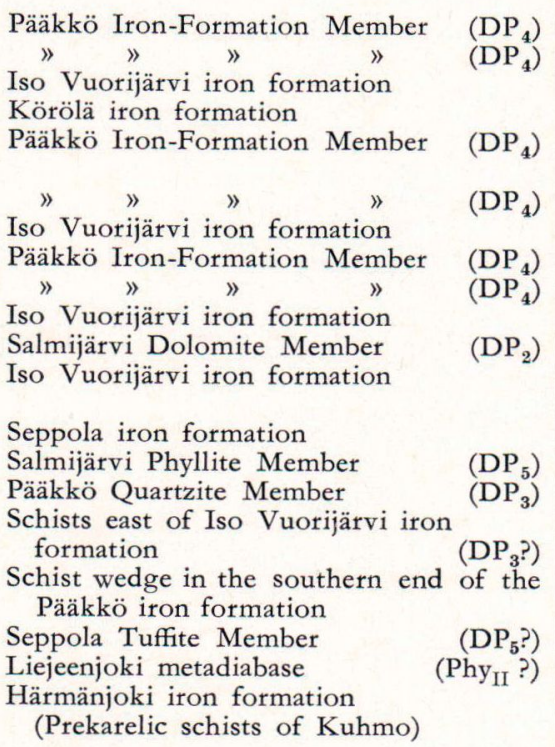 & 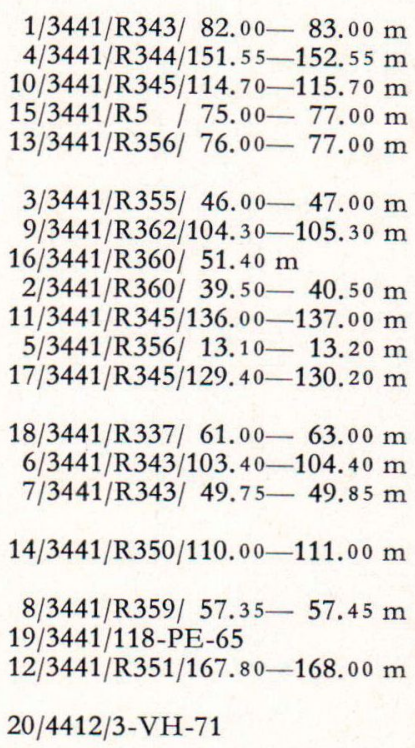 \\
\hline
\end{tabular}

Co-ordinates of the drill holes and outcrops outside the map area in Fig. 2 are; 4) $\mathrm{x}=7179.400, y=535.870$; 13) $\mathrm{x}=7185.550, \mathrm{y}=534.370 ; 18) \mathrm{x}=7184.540, \mathrm{y}=534.140 ; 20) \mathrm{x}=7145.280, \mathrm{y}=453.780$.

places Preglacial weathering has caused weak secondary enrichment of iron in this kind of rock (Laajoki 1975), in which case the rock contains limonite bands (No. 6) in addition to quartz and magnetite bands. Sample No. 7 is a rust-coloured iron-silicate-magnetite rock, which is considered to be weathered silicate-facies rock. The rocks of the carbonate facies are represented by samples Nos. 9 and 10 . The rocks of the oxide, silicate and carbonate facies are almost pure chemical sediments and they are considered as the iron formations proper. Sample No. 8 is from an apatite-rich band about $0.5 \mathrm{~cm}$ thick. The presence of apatite was verified by $\mathrm{X}$-ray diffraction studies made by P. Kallio. According to the $\mathrm{P}$ content (Table 2) the band contains approximately $70 \%$ apatite. Bands like these are especially characteristic of the rocks of the carbonate facies in the Pääkkö iron formation. In addition to apatite, they also contain quartz, sheet silicates, carbonates and carbonaceous, probably organogenic material. Some of them show faint pelletal features. The rocks of the sulphide facies (Nos. 12 and 13) seem to be a mixture of both clastic and nonclastic material. Samples Nos. 11, 14, 15 and 16 represent typical Marine Jatulian metasediments. Sample No. 17 is somewhat exceptional. Its iron content is so high that, according to the general definition by Gross (1965), the rock should be included in the iron formations. Its main constituents are amphiboles, biotite, garnet and clastic quartz. Moreover it contains accessory zircon and is relatively rich in $\mathrm{Ti}$ and poor in $\mathrm{P}$ (Table 2). Thus, it is a more or less clastic metasediment. Sample No. 18 is from a basic tuffitic metasediment. Meta- 
TABLE 2

REE concentrations (ppm) and P, Fetot, FeHCl, S, Mn and Ti contents (Wt-\%) in iron formations and associated Laboratory of the Technical Research Center of Finland. The other elements were analysed in the Ore Laboratory

\begin{tabular}{|c|c|c|c|c|c|c|c|c|c|c|}
\hline No. & $\mathrm{La}$ & $\mathrm{Ce}$ & $\mathrm{Nd}$ & $\mathrm{Sm}$ & $\mathrm{Eu}$ & $\mathrm{Gd}$ & $\mathrm{Tb}$ & Dy & Ho & $\mathrm{Tm}$ \\
\hline $\begin{array}{l}1 \ldots \\
2 \ldots \\
3 \ldots \\
4 \ldots \\
\end{array}$ & $\begin{array}{l}15.4 \\
17.5 \\
18.9 \\
17.1 \\
\end{array}$ & $\begin{array}{l}21.0 \\
13.0 \\
12.2 \\
15.5\end{array}$ & $\begin{array}{l}18.8 \\
26.0 \\
26.3 \\
18.6\end{array}$ & $\begin{array}{l}3.9 \\
4.4 \\
3.8 \\
3.3\end{array}$ & $\begin{array}{l}1.1 \\
1.3 \\
1.2 \\
1.2 \\
\end{array}$ & $\begin{array}{l}3.5 \\
\text { n.d. } \\
\text { n.d. } \\
\text { n.d. }\end{array}$ & $\begin{array}{l}0.78 \\
0.85 \\
0.75 \\
0.69\end{array}$ & $\begin{array}{l}4.5 \\
\text { n.d. } \\
\text { n.d. } \\
\text { n.d. }\end{array}$ & $\begin{array}{l}\left.1.1^{*}\right) \\
\left.1.2^{*}\right) \\
\left.0.9^{*}\right) \\
1.0\end{array}$ & $\begin{array}{l}0.62 \\
\text { n.d. } \\
\text { n.d. } \\
\text { n.d. }\end{array}$ \\
\hline A & 17.2 & 15.4 & 22.4 & 3.9 & 1.2 & $(3.5)$ & 0.77 & $(4.5)$ & (1.1) & $(0.62)$ \\
\hline $\begin{array}{c}5 \ldots \\
6 \ldots \\
7 \ldots \\
8 \ldots \\
9 \ldots \\
10 \ldots \\
11 \ldots \\
\end{array}$ & $\begin{array}{c}13.0 \\
18.1 \\
25.8 \\
104 \\
16.0 \\
18.4 \\
5.4\end{array}$ & $\begin{array}{l}22.5 \\
30.3 \\
17.1 \\
81.9 \\
13.3 \\
15.2 \\
12.4\end{array}$ & $\begin{array}{r}12.5 \\
13.4 \\
31.9 \\
146 \\
5.1 \\
13.5 \\
6.3\end{array}$ & $\begin{array}{r}3.2 \\
4.3 \\
5.4 \\
27.9 \\
4.2 \\
3.4 \\
1.7\end{array}$ & $\begin{array}{l}1.2 \\
1.3 \\
1.5 \\
9.9 \\
1.5 \\
0.83 \\
0.47\end{array}$ & $\begin{array}{l}3.5 \\
\text { n.d. } \\
\text { n.d. } \\
\text { n.d. } \\
1.9 \\
\text { n.d. } \\
\text { n.d. }\end{array}$ & $\begin{array}{l}0.64 \\
0.80 \\
1.0 \\
5.3 \\
0.82 \\
0.55 \\
0.30\end{array}$ & $\begin{array}{l}3.4 \\
\text { n.d. } \\
\text { n.d. } \\
\text { n.d. } \\
4.3 \\
\text { n.d. } \\
\text { n.d. }\end{array}$ & $\begin{array}{c}9.97 \\
\left.1.1^{*}\right) \\
1.5 \\
8.9 \\
\left.1.1^{*}\right) \\
<0.5 \\
\left.0.4^{*}\right)\end{array}$ & $\begin{array}{l}0.62 \\
\text { n.d. } \\
\text { n.d. } \\
\text { n.d. } \\
0.66 \\
\text { n.d. } \\
\text { n.d. }\end{array}$ \\
\hline $\begin{array}{l}12 \ldots \\
13 \ldots \\
\end{array}$ & $\begin{array}{l}37.3 \\
25.9\end{array}$ & $\begin{array}{l}45.8 \\
49.9\end{array}$ & $\begin{array}{l}42.8 \\
38.5\end{array}$ & $\begin{array}{l}8.7 \\
6.6 \\
\end{array}$ & $\begin{array}{l}2.7 \\
1.9 \\
\end{array}$ & $\begin{array}{l}\text { n.d. } \\
\text { n.d. }\end{array}$ & $\begin{array}{l}1.7 \\
1.2 \\
\end{array}$ & $\begin{array}{l}\text { n.d. } \\
\text { n.d. }\end{array}$ & $\begin{array}{l}\left.2.3^{*}\right) \\
1.0\end{array}$ & $\begin{array}{l}\text { n.d. } \\
\text { n.d. }\end{array}$ \\
\hline B & 31.6 & 47.9 & 40.7 & 7.7 & 2.3 & & 1.5 & & $(1.7)$ & \\
\hline $\begin{array}{l}14 \ldots \\
15 \ldots \\
\end{array}$ & $\begin{array}{l}21.3 \\
20.0 \\
\end{array}$ & $\begin{array}{l}40.9 \\
41.9\end{array}$ & $\begin{array}{l}28.4 \\
23.1 \\
\end{array}$ & $\begin{array}{l}7.1 \\
4.7 \\
\end{array}$ & $\begin{array}{l}1.3 \\
0.99 \\
\end{array}$ & $\begin{array}{l}\text { n.d. } \\
\text { n.d. }\end{array}$ & $\begin{array}{l}0.9 \\
0.78\end{array}$ & $\begin{array}{l}\text { n.d. } \\
\text { n.d. }\end{array}$ & $\begin{array}{l}1.5 \\
0.97\end{array}$ & $\begin{array}{l}\text { n.d. } \\
\text { n.d. }\end{array}$ \\
\hline $\mathrm{C}$ & 20.7 & 41.4 & 25.8 & 5.9 & 1.1 & & 0.84 & & 1.2 & \\
\hline $\begin{array}{l}16 \ldots \\
17 \ldots \\
18 \ldots \\
19 \ldots \\
20 \ldots\end{array}$ & $\begin{array}{l}14.3 \\
7.9 \\
0.63 \\
1.4 \\
3.4\end{array}$ & $\begin{array}{r}39.6 \\
23.1 \\
5.9 \\
1.9 \\
6.4\end{array}$ & $\begin{array}{r}17.0 \\
22.6 \\
<1.0 \\
1.3 \\
3.9\end{array}$ & $\begin{array}{l}3.6 \\
3.2 \\
2.4 \\
0.71 \\
0.72\end{array}$ & $\begin{array}{l}1.0 \\
0.79 \\
0.75 \\
0.40 \\
0.45\end{array}$ & $\begin{array}{l}\text { n.d. } \\
\text { n.d. } \\
\text { n.d. } \\
\text { n.d. } \\
\text { n.d. }\end{array}$ & $\begin{array}{l}0.81 \\
0.55 \\
0.65 \\
0.37 \\
0.18\end{array}$ & $\begin{array}{l}\text { n.d. } \\
\text { n.d. } \\
\text { n.d. } \\
\text { n.d. } \\
\text { n.d. }\end{array}$ & $\begin{array}{l}0.94 \\
0.81 \\
1.1 \\
0.51 \\
0.24\end{array}$ & $\begin{array}{l}\text { n.d. } \\
\text { n.d. } \\
\text { n.d. } \\
\text { n.d. } \\
\text { n.d. }\end{array}$ \\
\hline
\end{tabular}

n.d. = not determined. ${ }^{*}$ ) estimated from the distribution pattern. y) analysed by Risto Saikkonen. $\Sigma$ REE $=$

diabases of the early Karelidic magmatism are represented by sample No. 19.

For comparison one sample (No. 20) from the Prekarelidic iron formation of Kuhmo is included. The iron formations of Kuhmo are closely associated with basic volcanics (Hyppönen 1973) and thus belong to the Algoma type.

\section{Results and discussion}

The analytical data are given in Table 2. REE contents normalized to the composite of 40 North American shales (NAS), mostly Paleozoic in age, (Haskin et al. 1968, Table 2), are presented graphically in Figs. 4-9. For the normalization of Dy the estimated value $5.0 \mathrm{ppm}$ for NAS was used (Wildeman \& Haskin 1973).

REE in iron formations proper: If the REE contents of the iron formations proper in Väyrylänkylä (Table 2) are compared with those available in the literature (Balashov \& Goryainov 1966; Fryer 1971 a, b; Tugarinov et al. 1973; Wildeman \& Haskin 1973) and with the Kuhmo iron formation (No. 20) the exceptional abundance in REE of the Väyrylänkylä deposits becomes evident: their total REE content is about four times greater than that in Sokoman and Krivoy Rog. In Väyrylänkylä the REE content seems to be more or less directly proportional to the $\mathrm{P}$ content of the rock (Fig. 10 and the ratio $\Sigma \mathrm{REE} / \mathrm{Px} 10^{-3}$ in Table 2 ). This de- 
rocks. Sample descriptions are given in TABLE 1. REE analyses were performed by Riitta Zilliacus in the Reactor of the Chemistry Department, Geological Survey of Finland

\begin{tabular}{|c|c|c|c|c|c|c|c|c|c|c|}
\hline $\mathrm{Yb}$ & $\mathrm{Lu}$ & $\mathrm{Eu} / \mathrm{Sm}$ & $\Sigma$ REE & P \% & $\frac{\Sigma \mathrm{REE}}{\mathrm{P} \times 10^{-3}}$ & $\mathrm{Fe}_{\mathrm{HCl}} \%$ & $\mathrm{Fe}_{\text {tot } \%}$ & S \% & $\mathrm{Mn} \%$ & $\mathrm{Ti} \%$ \\
\hline 2.3 & 0.30 & 0.28 & 64.68 & 1.16 & 56 & 22.1 & 31.9 & 0.78 & 0.06 & 0.06 \\
\hline 1.7 & 0.30 & 0.30 & 66.25 & 1.45 & 46 & 23.9 & 34.4 & 0.82 & 0.02 & 0.02 \\
\hline 2.7 & 0.30 & 0.32 & 67.05 & 0.83 & 81 & 21.2 & 28.6 & 1.46 & 0.03 & 0.02 \\
\hline 1.4 & 0.25 & 0.36 & 59.04 & 1.44 & 41 & 16.3 & 24.0 & 0.68 & 0.08 & 0.07 \\
\hline 2.0 & 0.29 & 0.31 & 64.26 & & & & & & & \\
\hline 2.2 & 0.21 & 0.38 & 56.42 & 1.15 & 49 & 23.4 & 31.0 & 0.83 & 0.09 & 0.04 \\
\hline 1.2 & 0.25 & 0.30 & 70.75 & 1.15 & 62 & 26.8 & 30.0 & 1.06 & 0.01 & 0.03 \\
\hline 3.0 & 0.36 & 0.28 & 87.56 & 2.00 & 44 & 32.9 & 35.6 & 0.39 & 0.01 & 0.00 \\
\hline 11.5 & 1.11 & 0.35 & 396.51 & $12.8 \mathrm{y})$ & 31 & n.d. & n.d. & n.d. & n.d. & n.d. \\
\hline 2.7 & 0.29 & 0.36 & 45.01 & 1.44 & 31 & 26.6 & 28.0 & 1.03 & 0.02 & 0.02 \\
\hline 0.99 & 0.20 & 0.24 & $\lesssim 53.57$ & 0.89 & 60 & 22.8 & 22.9 & 0.42 & 0.05 & 0.03 \\
\hline 0.54 & 0.10 & 0.28 & 27.61 & 0.14 & 197 & 1.92 & 2.06 & 0.18 & 0.12 & 0.11 \\
\hline 6.3 & 0.98 & 0.31 & 148.58 & 0.50 & 297 & 20.3 & 20.3 & 9.65 & 0.03 & 0.33 \\
\hline 3.3 & 0.44 & 0.29 & 128.74 & 0.38 & 339 & 19.9 & 20.5 & 10.9 & 1.63 & 0.14 \\
\hline 4.8 & 0.71 & 0.30 & 138.91 & & & & & & & \\
\hline 2.4 & 0.47 & 0.18 & 104.27 & 0.14 & 745 & 7.17 & 8.13 & 4.57 & 0.06 & 0.43 \\
\hline 2.0 & 0.32 & 0.21 & 94.76 & 0.11 & 861 & 7.24 & 7.28 & 0.27 & 0.02 & 0.69 \\
\hline 2.2 & 0.40 & 0.19 & 99.54 & & & & & & & \\
\hline 1.4 & 0.23 & 0.28 & 78.88 & 0.18 & 438 & 10.1 & 10.5 & 0.21 & 0.12 & 0.68 \\
\hline 1.5 & 0.26 & 0.25 & 60.71 & 0.16 & 379 & 12.6 & 21.8 & 0.20 & 0.04 & 0.54 \\
\hline 2.5 & 0.33 & 0.31 & $\lesssim 15.26$ & 0.09 & 170 & 7.98 & 9.99 & 0.12 & 0.14 & 0.72 \\
\hline 1.1 & 0.21 & 0.56 & 7.90 & 0.10 & 123 & 5.00 & 8.02 & 0.32 & 0.15 & 0.30 \\
\hline 0.57 & 0.13 & 0.63 & 15.99 & 0.09 & 178 & 21.9 & 25.5 & 0.57 & 0.25 & 0.02 \\
\hline
\end{tabular}

$\Sigma(\mathrm{La}, \mathrm{Ce}, \mathrm{Nd}, \mathrm{Sm}, \mathrm{Eu}, \mathrm{Tb}, \mathrm{Ho}, \mathrm{Yb}, \mathrm{Lu}) . \mathrm{A})$ Average of 1-4. B) Average of 12-13. C) Average of $14-15$.

pendence is especially marked when the apatiterich band (No. 8) is compared with the other iron-formation samples (Nos. 1-7, 9, and 10).

Ce is depleted in the REE distribution patterns (Figs. 4 a, 5 a, 7, and 9 a). The REE content and distribution pattern of the apatite-rich band in Pääkkö is of the same type as those in the apatites from Florida, in the pelletal phosphorites from Queensland and in the metalliferous sediments from the Pacific Ocean (Fig. 9). The marked depletion of $\mathrm{Ce}$ and the relatively low average total REE content in the apatites from the Bone Valley Formation of Florida, the Phosphoria Formation and the Morroccan deposits, are ascribed to the fact that they were formed in a marine environment (Altschuler et al. 1967;
Fleischer \& Altschuler 1969). The pelletal phosphorites of Queensland are considered to have been formed under shallow marine conditions (Cook 1972). The REE patterns of the sediments from the Pacific Ocean imply either that the REE were coprecipitated from sea water with ironmanganese hydroxyoxides, or that they are incorporated in the phosphatic fish debris found in all samples (Dymond et al. 1973; of. also Bender et al. 1971). Thus, the apatite-rich band in Pääkkö seems to be a marine phosphorite interband. Consequently, the apatite in the Väyrylänkylä iron formations is of marine origin. The Ce-depleted REE patterns of the oxide, silicate and carbonate facies are due to the REE incorporated in this apatite. 


\section{SEPPOLA SECTION ISO VUORIJÄRVI SECTION PÄÄKKÖ SECTION}

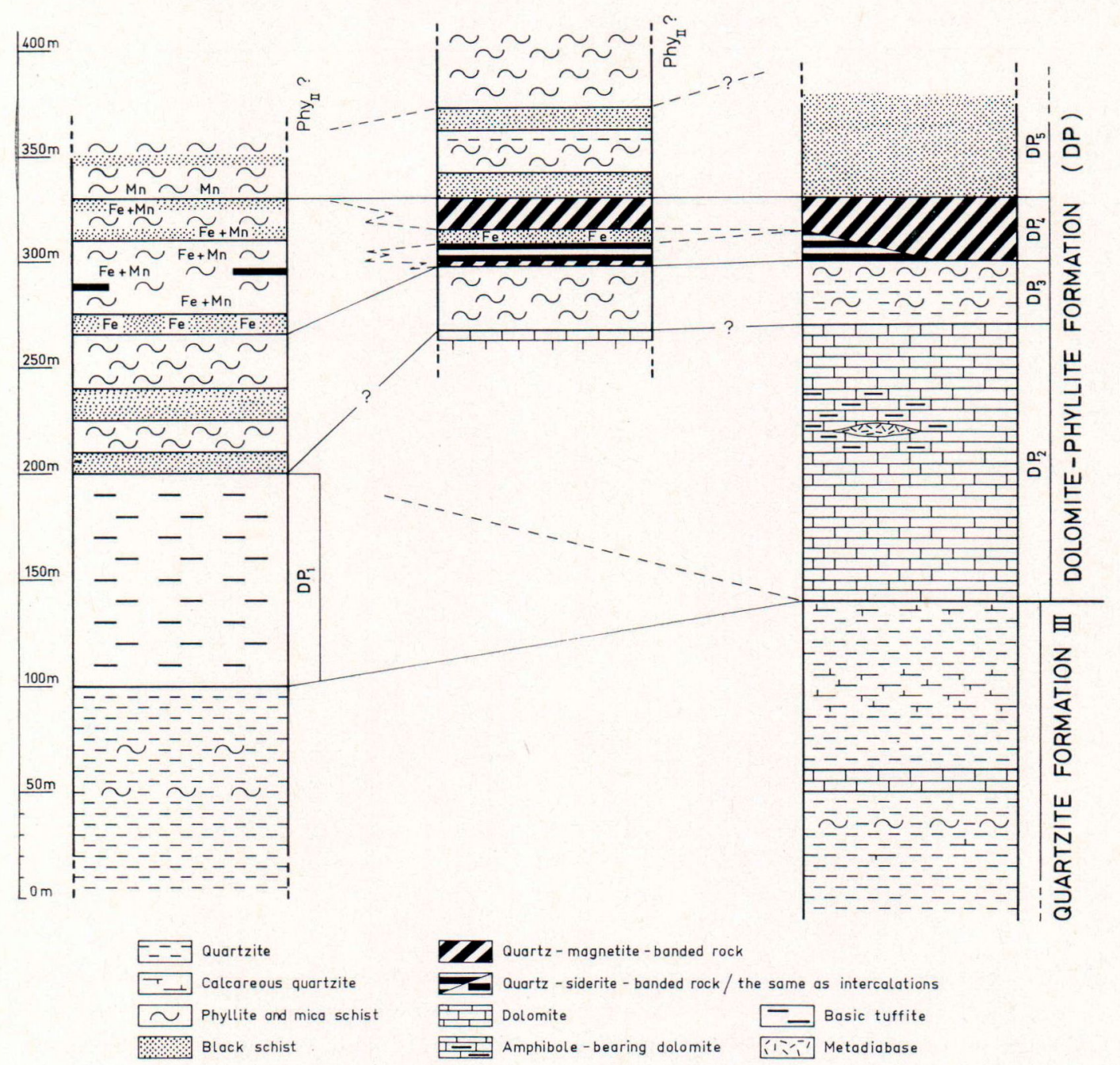

Iron-rich ( $\left.\mathrm{Fe}_{\text {tot }}>15 \%\right)$ and/or manganese-bearing $\left(\mathrm{Mn}_{n}>1 \%\right)$ black schists and phyllites indicated by Fe and/or Mn

Fig. 3. Stratigraphic columns from the different sections in the Salmijärvi basin.

In general the REE contents and distribution patterns of the oxide, silicate and carbonate facies are similiar (Fig. 7). They all show clear trend towards relative depletion of the lighter REE and $\mathrm{Yb}$ and $\mathrm{Lu}$ in comparison with the NAS. The REE contents and distributions in the quartz-magnetite-banded rocks from Pääkkö, Iso Vuorijärvi and Körölä are almost identical (Fig.
4 a), which indicates a structural-stratigraphic interpretation in the light of which these deposits belong to the same metasedimentary horizon.

The effects of surface weathering on the REE distribution pattern can be seen in sample No. 6 (Fig. 4 b). The rock seems to be more enriched in $\mathrm{Ce}$ and more depleted in $\mathrm{Nd}$ than do the 
fresh rocks. Thus, $\mathrm{Ce}$ is only slightly depleted in this sample. These observations indicate that samples Nos. 5 and 9 and probably No. 1, too, are all somewhat affected by weathering. In Sokoman Fryer (1971 b) detected that »altered» oxide facies rocks show relative enrichment in heavy REE. However, the REE distribution pattern of the weathered silicate-facies rock (Fig. 7 , No. 7) is normal. This rock does not contain

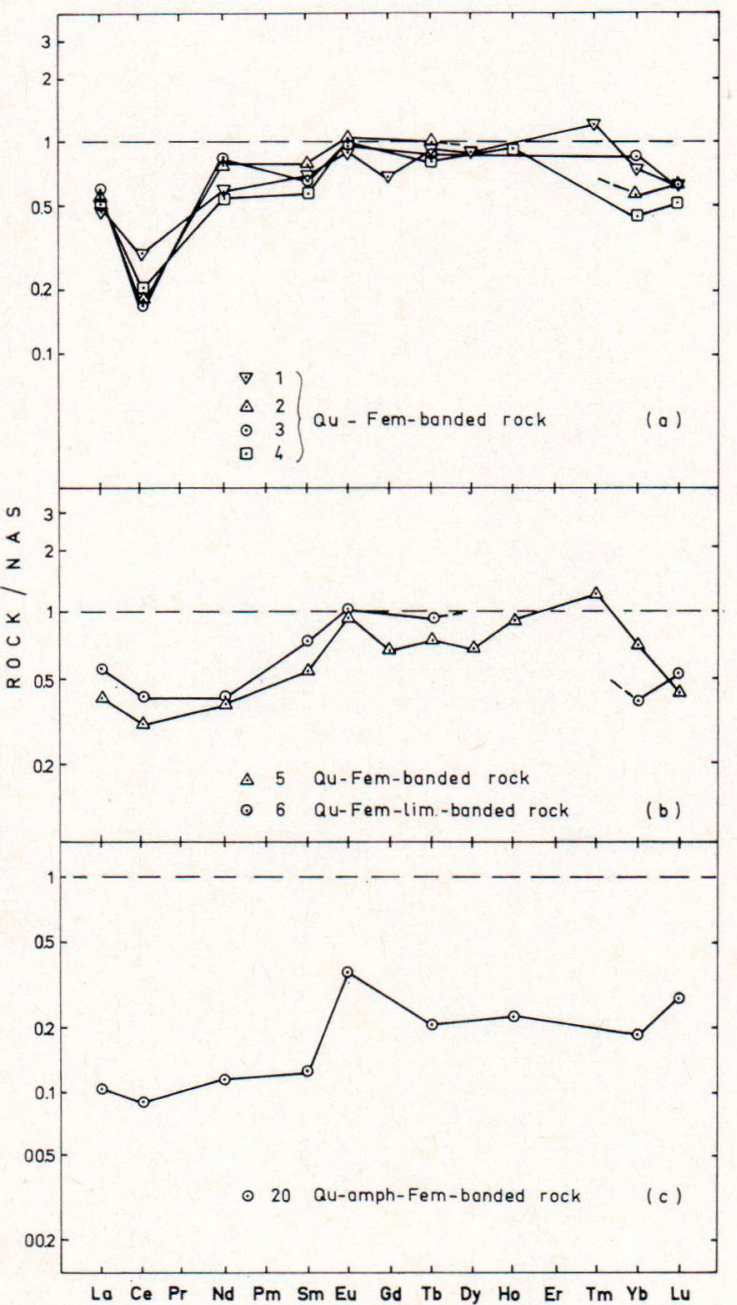

Fig. 4. NAS-normalized REE distribution patterns for (a) oxide facies and (b) altered oxide facies of the Väyrylänkylä iron formations and for (c) iron formation of Kuhmo. Mineral abbreviations used in Figs. $4-11$ are as follows: $\mathrm{qu}=$ quartz, Fem $=$ magnetite, $\mathrm{si}=$ siderite, $\lim =$ limonite, $\mathrm{amph}=$ amphibole, $\mathrm{bi}=$ biotite.

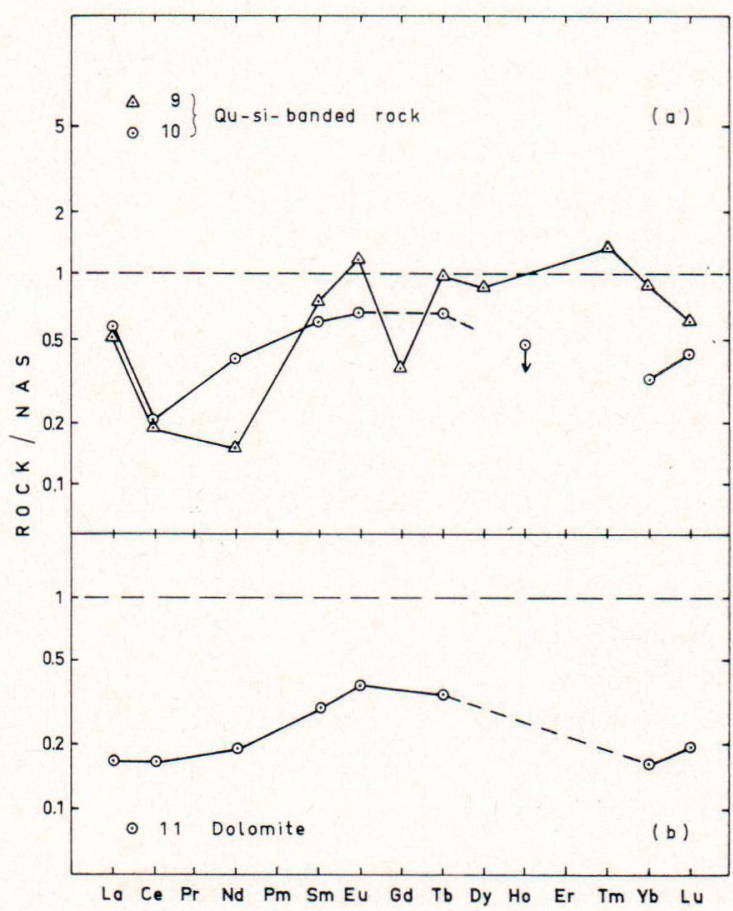

Fig. 5. NAS-normalized REE distribution patterns for (a) carbonate facies of the Pääkkö and Iso Vuorijärvi iron formations and for (b) Salmijärvi dolomite.

limonite, and hence, the effects described are probably due to the formation of limonite.

$R E E$ in sulphide-facies rocks: The REE content and distribution pattern of the sulphide facies deviates from those of other iron-formation facies in that its Ce depletion is less pronounced and it is richer in REE (Fig. 7). In this respect the sulphide-facies rocks resemble normal clastic metasediments, black schist and phyllites (Fig. 6). They evidently contain REE incorporated both in marine apatite, the amount of which is markedly lower than that in the iron formations proper as indicated by $\mathrm{P}$ contents (Table 2), and in clastic material (Fig. 10). The composite nature of this iron-formation facies is thus also apparent in the REE. There does not seem to be any marked difference between the REE in the manganiferous (No. 13) and the ordinary iron-rich black schist (No. 12). The more obvious 
depletion of $\mathrm{Ce}$ in the latter rock is to be ascribed to the higher $\mathrm{P}$ (apatite) content (Table 2).

$R E E$ in associated rocks: Marine Jatulian pelitic metasediments (Nos. 14-16) have lower total REE contents and show a clear trend towards depletion of the lighter REE and $\mathrm{Yb}$ and $\mathrm{Lu}$ compared with the NAS (Fig. 6). The average REE distribution of the black schist and phyllite (Table 2, B) is, however, very close to that of the clays and shales of the geosynclines (Ronov et al. 1974; Table 6) and shows only a slight depletion of $\mathrm{La}$ and Ce. Their REE distributions also exhibit similarities with schists from southern Lapland (Sahama 1945), and with the Karelian black schist from Outokumpu (Wildeman \& Haskin 1973, Table 2). With the exception of Ce, the iron formations and Marine Jatulian pelitic metasediments have similiar REE distribution patterns. This is especially obvious between the quartz-magnetite-banded rock and the amphibole-bearing phyllite (Table 2, A and No. 16).

The Salmijärvi dolomite (No. 11) has an REE pattern close to the average of the carbonates in the geosynclines (Ronov et al. 1974; Table 6). Compared with the quartz-siderite-banded rock (Table 2, No. 10) it is depleted in La by a factor of 0.29 , in Ce by a factor of 0.82 , and in $\mathrm{Nd}$, $\mathrm{Sm}, \mathrm{Eu}, \mathrm{Tb}, \mathrm{Yb}, \mathrm{Lu}$ by a factor of $0.47-0.57$. For comparison between the dolomite and pelitic metasediments (Table 2, B), the depletion factor is $0.24-0.36$ for $\mathrm{La}, \mathrm{Ce}, \mathrm{Nd}, \mathrm{Sm}, \mathrm{Tb}, \mathrm{Yb}$ and Lu. For Eu, however, it is markedly greater, being 0.43 . Thus, the REE distribution pattern in the dolomite is closer to that in pelitic rocks than that in the carbonate-facies rock of the iron formations. This suggests that the REE are mainly incorporated in the clastic material of the dolomite (cf. Fryer 1971 b, p. 102).

The REE content and distribution in the Liejeenjoki metadiabase (No. 19) resemble those detected by Sahama (1945) in the gabbros and metadiabases in southern Lapland. Both the Liejeenjoki metadiabase and Seppola tuffite (No. 18) show a clear relative depletion of lighter REE (Fig. 8). The amphibole-biotite-garnet rock

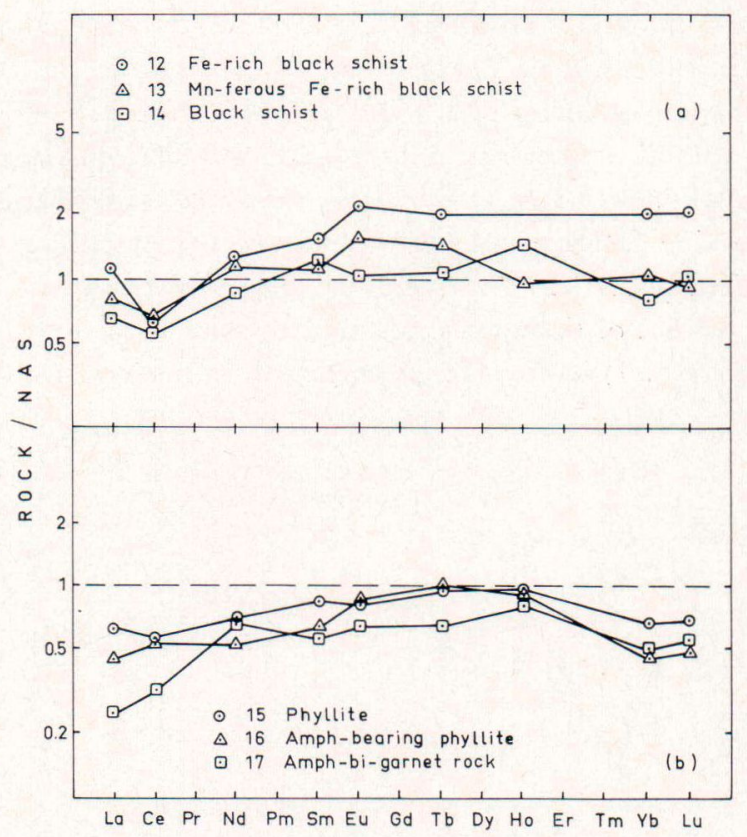

Fig. 6. NAS-normalized REE distribution patterns for (a) black schists and (b) phyllites and amphibole-biotitegarnet rock of the Salmijärvi basin.

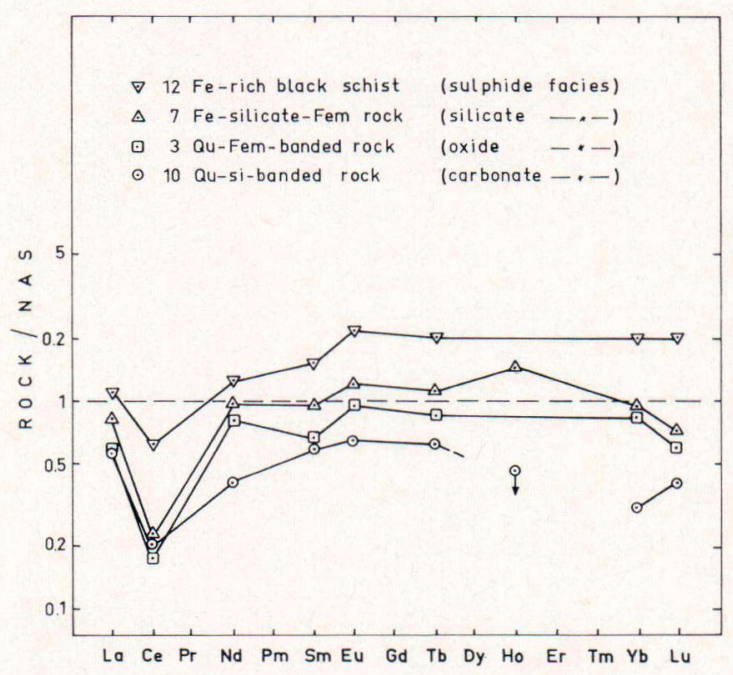

Fig. 7. NAS-normalized REE distribution patterns for the different facies of the Iso Vuorijärvi iron formation.

(No. 17) is more depleted in lighter REE than the pelitic rocks (Fig. 6). This may indicate that it contains relatively more tuffaceous material or material derived from basic rocks. On the other 
TABLE 3

Eu: Sm ratio in Precambrian iron formations and in metalliferous Pacific sediments

\begin{tabular}{|c|c|c|c|c|c|c|}
\hline \multirow{2}{*}{ Occurrence } & \multirow{2}{*}{ Type } & \multirow{2}{*}{ Age (Ma) } & \multicolumn{4}{|c|}{$\mathrm{Eu}: \mathrm{Sm}$} \\
\hline & & & Analyses & Average & Range & References \\
\hline Michipicoten . & Algoma & $\left.2750-2700^{1}\right)$ & 2 & 0.91 & $1.11-0.71$ & Fryer 1971 a \\
\hline Timagami ....... & $»$ & $\left.>2450^{2}\right)$ & 2 & 0.70 & $0.51-0.89$ & " \\
\hline Kuhmo ........... & $»$ & $\left.>2740^{3}\right)$ & 1 & 0.63 & & This study \\
\hline Mary River...$\ldots$ & " & Archean? 4 ) & 6 & 0.57 & $0.36-0.82$ & Fryer 1971 a \\
\hline Wyoming $\ldots \ldots \ldots$ & Algoma? & $\left.>2687^{5}\right)$ & 1 & 0.44 & & $\begin{array}{l}\text { Wildeman \& Haskin } \\
1973\end{array}$ \\
\hline Olenogorsk & Algoma & $\left.>2700^{6}\right)$ & 1 & 0.40 & & $\begin{array}{l}\text { Balashov \& } \\
\quad \text { Goryainov } 1966\end{array}$ \\
\hline Biwabik ....... & Superior & $\left.2200-1900^{7}\right)$ & 1 & 0.43 & & $\begin{array}{l}\text { Wildeman \& Haskin } \\
1973\end{array}$ \\
\hline $\begin{array}{l}\text { Sokoman } \\
\text { (oxide facies) }\end{array}$ & » & $\left.1870^{8}\right)$ & 8 & 0.34 & $0.23-0.42$ & Fryer 1971 b \\
\hline $\begin{array}{l}\text { Sokoman } \\
\text { (carbonate facic }\end{array}$ & & & & 0.04 & $0.23=0.42$ & Fryer 1971 b \\
\hline Krivoy Rog ....... & $\begin{array}{l}\prime \prime \\
\prime \prime\end{array}$ & $\begin{array}{r}\left.1870^{8}\right) \\
\left.2000-1800^{9}\right)\end{array}$ & $\begin{array}{r}6 \\
11\end{array}$ & $\begin{array}{l}0.33 \\
0.33\end{array}$ & $\begin{array}{l}0.20-0.55 \\
0.25-0.45\end{array}$ & $\begin{array}{l}\text { " } \\
\text { Tugarinov et al } 1973\end{array}$ \\
\hline Väyrylänkylä ...... & $»$ & $\left.2080^{10}\right)$ & 11 & 0.31 & $0.28-0.38$ & $\begin{array}{l}\text { Tugarinov et al. } 1973 \\
\text { This study }\end{array}$ \\
\hline Pacific Ocean . & & $\left.60-30^{11}\right)$ & 6 & 0.30 & $0.28-0.36$ & Dymond et al. 1973 \\
\hline
\end{tabular}

1) Goldich 1973. ${ }^{2}$ ) Fryer 1971 a. ${ }^{3}$ ) Geological Survey of Finland 1973, p. 16. ${ }^{4}$ ) Fryer 1971 a. ${ }^{5}$ ) Naylor et al. 1970. $\left.{ }^{6}\right)$ Lazarev, oral report 1974. ${ }^{7}$ ) Goldich 1973. ${ }^{8}$ ) Fryer 1972. ${ }^{9}$ ) Semenenko 1973. ${ }^{10}$ ) Sakko \& Laajoki 1975. ${ }^{11}$ ) Dymond et al. 1973.

hand its high iron content (Table 2) and close association with the Pääkkö iron formation suggest that it was more probably originated from the iron-formation material through reworking, during which process the phosphatic material and to it bounded REE were leached out.

General discussion: Quartz-amphibole-magnetite-banded rock from the Archean iron formation of Kuhmo (No. 20) is low in total REE and shows a much greater positive Eu-anomaly than do the Superior-type iron formations in Väyrylänkylä (Fig. 4). Moreover it is relatively more enriched in heavy REE, especially $\mathrm{Yb}$ and Lu. In Table 3 the Eu: Sm ratios in iron formations of different ages are compared. The older rocks seem to be relatively more enriched in $\mathrm{Eu}$. The relative growth in $\mathrm{Eu}$ content and the increase in the amount of heavy lanthanides

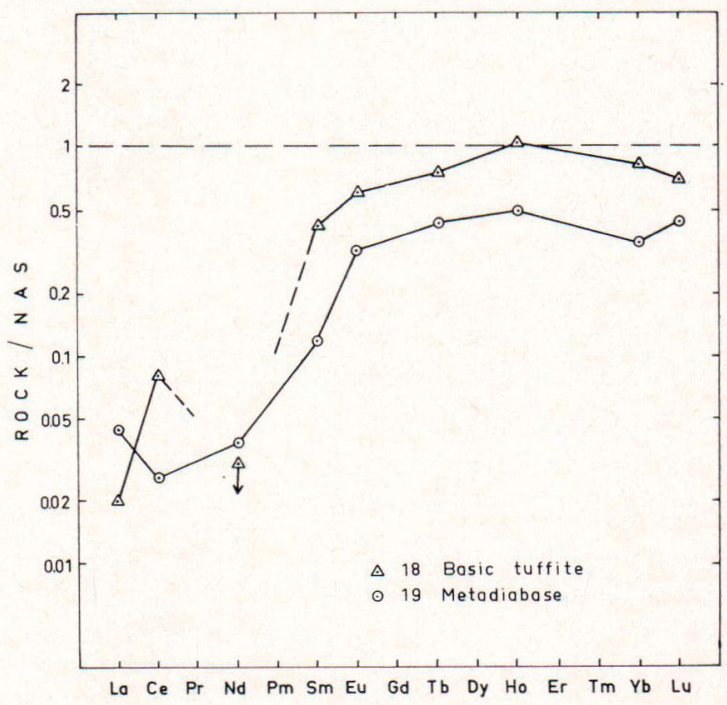

Fig. 8. NAS-normalized REE distribution patterns for Seppola tuffite and Liejeenjoki metadiabase. 


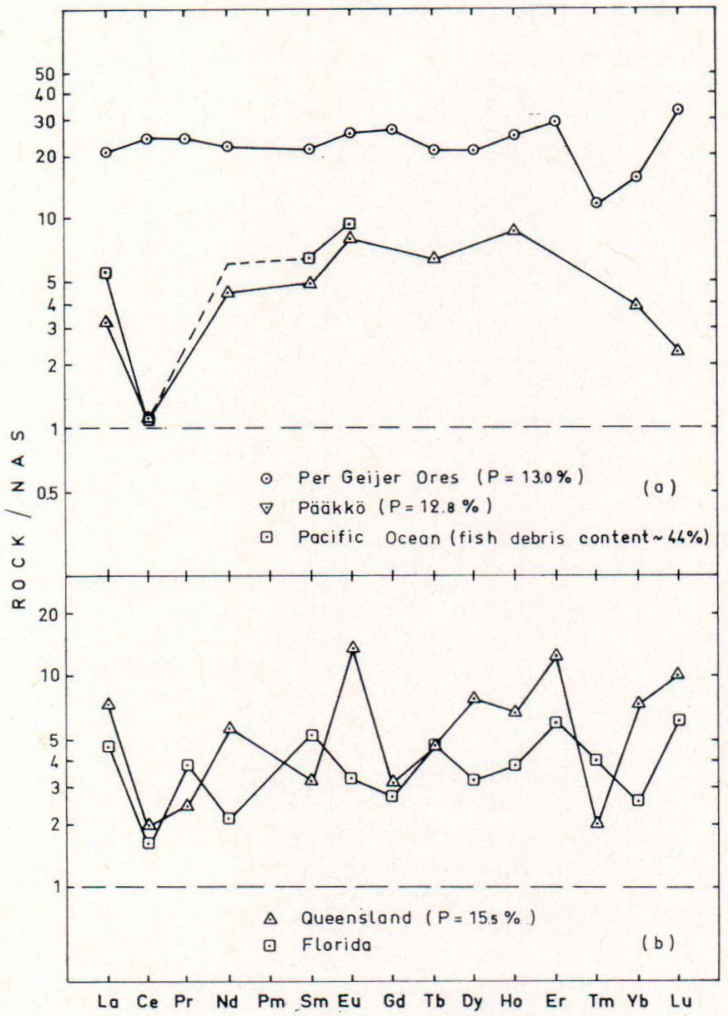

Fig. 9. NAS-normalized REE distribution patterns for (a) the average of the apatite concentrates of Per Geijer ores (Kiruna) (Parák 1973 a, Table 1, Nos. 6-16), apatiterich band in the Pääkkö iron formation (sample No. 8 in this study), and the average of three metalliferous sediments rich in fish debrish from the Pacific Ocean (Dymond et al. 1973, Table 2, Nos. 38-5-3, 39-2-3, 39-2-6), and for (b) the average of three pelletal phosphorites from Queensland (Cook 1972, Table 4, No. 11), and the average of three apatite concentrates from Florida (Altschuler et al. 1967, Table 1.)

through geological time have been discussed by several authors (Balashov \& Goryainov 1966; Fryer 1971 a, b; Wildeman \& Haskin 1973; Ronov et al. 1974). The observations by Fryer (1974, written personal communication), which have not revealed any positive Eu anomaly in iron formations younger than $2000 \mathrm{Ma}$, further confirm the secular changes in Eu in iron formations. The similarity in the Eu: $\mathrm{Sm}$ ratio between the iron formations in Krivoy Rog, Sokoman and in Puolanka is striking. However, Piper
(1974) and Cullers et al. (1974) have shown that REE distribution patterns can be strongly dependent on depositional environments, as is indicated by the positive correlation between Algoma-type iron formations and the high $\mathrm{Eu}: \mathrm{Sm}$ ratio in Table 3. In spite of their great age difference (c. $2000 \mathrm{Ma}$ ) both the Väyrylänkylä iron formations and the Pacific metalliferous sediments have almost identical Eu: $\mathrm{Sm}$ ratios (Table 3). More REE data are needed before any definitive conclusion can be drawn about the time dependence of the Eu: $\mathrm{Sm}$ ratio in iron formations.

REE in different types of phosphorus-bearing iron-rich rocks are compared in Fig. $9 \mathrm{a}^{1}$ ). The relatively low REE contents and the Ce depletion in the Pääkkö iron formation and in the metalliferous sediments from the Pacific Ocean indicate similar depositional environments (marine). The totally different REE pattern for the Per Geijer ores suggests a different (nonmarine?) origin for

1) It should be born in mind that the samples compared in this figure are of different types: some are apatite concentrates, some sediments and one is a metasedimentary interband (see discussion in Altschuler et al. 1967, p. B3).

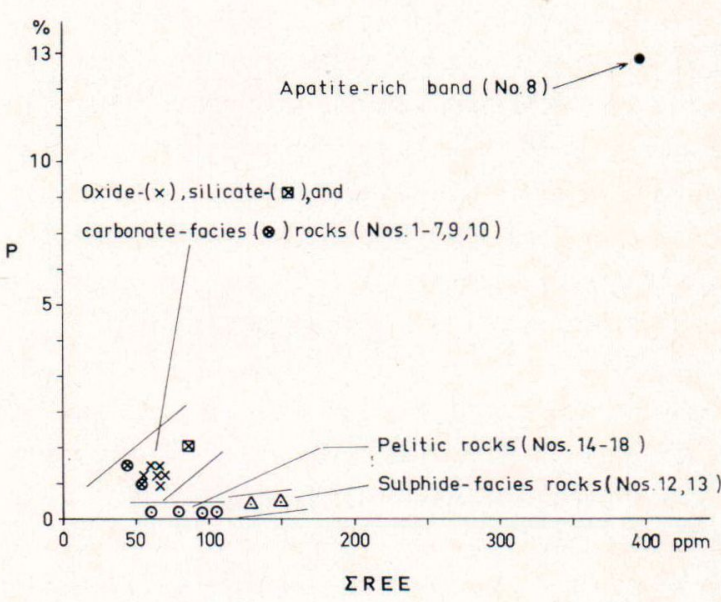

Fig. 10. Phosphorus concentration versus $\Sigma$ REE in oxide-, carbonate-, and sulphide-facies rocks and apatiterich band in Väyrylänkylä iron formations and in associated pelitic rocks. 


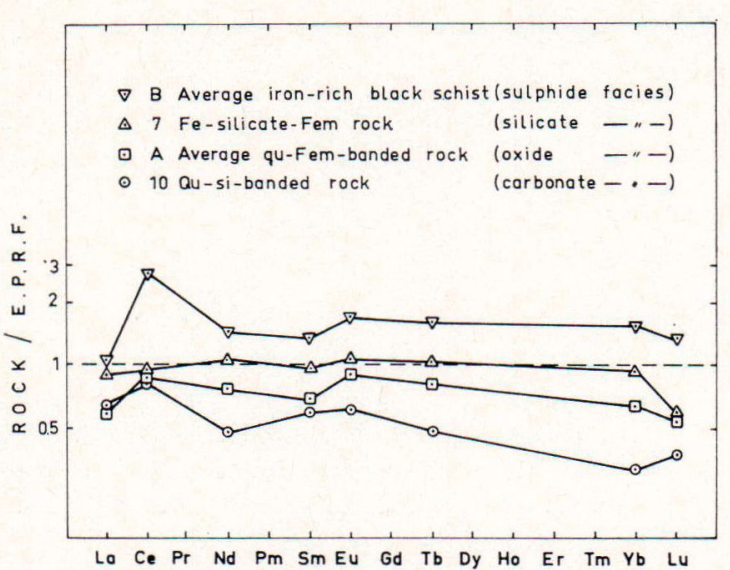

Fig. 11. REE distribution patterns for the oxide-, silicate-, carbonate-, and sulphide-facies rocks from the Väyrylänkylä iron formations normalized to the average flank sediments from the East Pacific Rise (E.P.R.F.) (Piper\& Graef 1974).

the apatite in Kiruna-type ores (cf. concepts in Parák 1973 b; Frietsch 1973, 1974; Geijer \& Ödman 1974).

After this manuscript was compiled a comprehensive paper concerning REE in sediments from the East Pacific Rise has been published (Piper \& Graef 1974). Here too, a seawater source for REE seems unequivocal. The REE distribution and content in the flank sediments from this Rise are very similiar to those in the oxide-facies rocks and, in particular, to those in the silicatefacies rock of the Väyrylänkylä iron formations (Fig. 11). In this comparison the composite nature of the sulphide-facies rocks is revealed by a positive $\mathrm{Ce}$ anomaly. The slight relative enrichment of the lighter REE of the carbonatefacies rock may indicate that this rock contains somewhat more clastic material than do other rocks of the iron formations proper. Thus, in the Väyrylänkylä iron formations the REE distribution in phosphorus-rich rock (apatite-rich band, Fig. 9 a) is close to those in the Pacific sediments relatively rich in fish debris (Dymond et al. 1973), whereas the REE distributions in the rocks relatively poor in phosphorus (oxide-, silicate-, and carbonate-facies rocks, Fig. 11) are similiar to those in the Pacific sediments poor in fish debris (Piper \& Graef 1974).

\section{Conclusions}

1) The comparatively high REE content and depletion of $\mathrm{Ce}$ in the Precambrian iron formations in Väyrylänkylä are due to the presence of marine apatite.

2) The similiar REE contents and distributions in the prevailing quartz-magnetite-banded rocks from the Pääkkö, Iso Vuorijärvi, and Körölä iron formations reinforce the opinion that they represent the same stratigraphic horizon.

3) The sulphide-facies rocks contain REE incorporated in both marine apatite and clastic material.

4) With the exception of Ce, the REE distribution patterns in both iron-formation rocks and pelitic metasediments are relatively similiar.

5) The REE distribution pattern in dolomite is closer to that in pelitic rocks than that in carbonate-facies rocks of iron formations, which suggests that the REE are incorporated mainly in the clastic material of the dolomite.

6) The Eu: $\mathrm{Sm}$ ratio in the Precambrian iron formations seems to be time-bound, but more REE data from geologically well-known deposits are needed before any definitive conclusions can be drawn in this respect.

7) The REE content and distribution of apatite in different kinds of iron-rich rocks elucidates the genesis of these deposists.

Acknowledgments - I wish to express my particular gratitude to Mrs. Riitta Zilliacus, M.Sc., of the Reactor Laboratory of the Technical Research Center of Finland, for the REE analyses. Dr. Tapio Koljonen of the University of Helsinki kindly read the paper and made valuable suggestions. I am also indebted to the following staff members of the Geological Survey of Finland: the personnel of the Ore Laboratory and Mr Risto Saikkonen, M.Sc., for chemical analyses (Chemistry Department); Mr Pekka Kallio, M.Sc., for X-ray determina- 
tions; Dr. Olavi Kouvo for directing my attention to Fryer's doctoral papers; Mr Viljam Hyppönen, M.Sc., for the sample from Kuhmo (Petrological Depatment); Mrs. Marjo-Riitta Kujala-Tammi and Mrs. Aino Lehti for drawing the figures; Dr. Lauri Hyvärinen for the compliance he showed to this study, Drs. Ilmari Haapala and Jaakko Siivola for critically reading the paper (Exploration Department).

\section{REFERENCES}

Altschuler, Z. S.; Berman, S. and Cuttitta, F. (1967) Rare earths in phosphorites - geochemistry and potential recovery. U. S. Geol. Surv. Prof. Paper $575-\mathrm{B}, \mathrm{B} 1-\mathrm{B} 9$.

Balashov, Yu. A. and Goryainov, P. M. (1966) Rare earth elements in the Precambrian iron-bearing rocks of the Imandra Region. Geochem. Int. 3: 240-251.

Bender, M.; Broecker, W.; Gornitz, V.; Middel, U.;

KAY, R.; Sun, S. -S. and BISCAYE, P. (1971) Geochemistry of three cores from the East Pacific Rise. Earth and Plan. Sci. Lett. 12: 425-433.

Cook, P. J. (1972) Petrology and geochemistry of the phosphate deposits of Northwest Queensland, Australia. Econ. Geol. 67: 1193-1213.

Cullers, R. L.; Yeh, L.-T.; Chaudhuri, S. and GuidotTr, C. V. (1974) Rare earth elements in Silurian pelitic schists from N. W. Maine. Geochim. Cosmochim. Acta 38: 389-400.

Dymond, J.; Corliss, J. B.; Heath, G. R.; Field, C. W., DAsch, E. J. and VEeH, H. H. (1973) Origin of metalliferous sediments from the Pacific Ocean. Geol. Soc. Am. Bull. 84: 3355-3372.

Fleischer, M. and Altschuler, Z. S. (1969) The relationship of the rare-earth composition of minerals to geological environment. Geochim. Cosmochim. Acta 33: $725-732$.

FrietsCh, R. (1973) The origin of the Kiruna iron ores. Geol. Fören. Stockholm Förh. 95: 375-380.

- (1974) The occurrence and composition of apatite with special reference to iron ores and rocks in Northern Sweden. Sveriges. Geol. Unders. Ser C, No. 694. 49 p.

Fryer, B. J. (1971 a) Age and trace element compostitions of Algoma-type iron-formations of the Canadian Shield. Pp. 85-96 in Variations in isotopic abundances of strontium, calcium, and argon and related topics. M.I.T. - 1381-19. Massachusetts Inst. of Technol.

- (1971 b) Trace element composition of the Sokoman iron-formation, Labrador Trough. Pp. 96-111 in Varations in isotopic abundances of strontium, calcium, and argon and related topics. Massachusetts Inst. of Tecnhnol.

- (1972) Age determinations in the Circum-Ungava geosyncline and the evolution of Precambrian banded iron-formations. Can. J. Earth Sci. 9. 652-663.

Geijer, P. and Ödman, O. H. (1974) The emplacement of the Kiruna iron ores and related deposits. Sveriges. Geol. Unders. Ser. C, No. 700. 48 p.

Geological Survey of Finland (1973) Annual report on the activities for the year 1972 (in Finnish with an English summary). 59 p.

Geological Survey of Finland (1974) Annual report on the activities for the year 1973 (in Finnish with an English summary). 62 p.

Goldich, S. S. (1973) Ages of Precambrian banded iron-formations. Econ. Geol. 68: 1126-1134.

Gross, G. A. (1965) Geology of iron deposits in Canada. Vol I, General geology and evaluation of iron deposits. Geol. Surv. Can., Econ. Geol. Rep. No. 22. 182 p.

Haskin, L. A.; Haskin, M. A.; Frey, F. A. and WildeMAN, T. R. (1968) Relative and absolute terrestial abundances of the rare earths. Pp. 889-912 in Origin and Distribution of the Elements, ed. by L. H. Ahrens. Pergamon Press, London.

Hyppönen, V. (1973) [Map of Pre-Quaternany rocks], 4412 Hiisijärvi. General Geogical Map of Finland, 1: 100000.

Koljonen, T. and Rosenberg, R. J. (1974) Rare earth elements in granitic rocks. Lithos 7: 249-261.

LaAjoki, K. (1973) On the geology of the South Puolanka Area, Finland. Bull. Geol. Surv. Finland. 263. $42 \mathrm{p}$.

- (1975) On the stratigraphic postion of kaolin in Väyrylänkylä, South Puolanka Area, Finland. Bull. Geol. Soc. Finland. 47: 83-91.

LANDERGREN, S. (1936) En orienterande undersökning över elementfördelningen i några svenska järnmalmstyper. Jernk. Ann. 91: 711-737.

- (1948) On the geochemistry of Swedish iron ores and associated rocks. Sveriges Geol Unders. Ser. C, No. 496. 182 p.

Naylor, R. S.; Steiger, R. H. and Wasserburg, G. J. (1970) U-Th- $\mathrm{Pb}$ and Rb-Sr systematics in $2700 \times$ $10^{6}$-year old plutons from the southern Wind River Range, Wyoming. Geochim. Cosmochim. Acta 34: 1133-1159.

PARÁk, T. (1973 a) Rare earths in the apatite iron ores 
of Lappland together with some data about the Sr, Th and $\mathrm{U}$ content of these ores. Econ. Geol. 68: 210-221.

- (1973 b) Kirunamalmernas bildning. Doctorate thesis. Stockholm Univ. Printed at Luleå. 222 p.

Piper, D. Z. (1974) Rare earth elements in ferromanganese nodules and other marine phases. Geochim. Cosmochim. Acta 38. 1007-1022.

Piper, D. Z. and Graef, P. A. (1974) Gold and rareearth elements in sediments from the East Pacific Rise. Marine Geol. 17: 287-297.

Ronov, A. B.; Balashov, Yu. A.; Girin, Yu. P.; Braтіsнко, R. Kh. and Kazakov, G. A. (1974) Regularities of rare-earth element distribution in the sedimentary shell and in the crust of the earth. Sedimentol. 21: $171-193$.

RosenberG, R. J. (1972) Instrumental activation analysis of Lunar samples. Suomen kemistilehti B 45: 399404.

Rosenber G, R. J. and Wirk, H. B. (1971) Instrumental activation analysis of 11 lanthanide elements in Apollo 12 Lunar samples. Radiochim. Radioanal. Lett. 6: 45.
Sahama, Th. G. (1945) Spurenelemente der Gesteine im südlichen Finnish-Lappland. Bull. Comm. Géol. Finlande 135. 86 p.

SAKKo, M. and LAAjokI, K. (1975) Whole rock Pb-Pb isochron age for the Pääkkö iron formation in Väyrylänkylä, South Puolanka Area, Finland. Bull. Geol. Soc. Finland. 47: 113-117.

Semenenko, N. P. (1973) The iron-chert formations of the Ukrainian shield. In Genesis of Precambrian iron and manganese deposits. Proceedings of the Kiev Symposium, 20-25 August 1970. Unesco, Earth Sci. 9: $135-142$.

Simonen, A. (1960) Pre-Quaternary rocks in Finland. Bull. Comm. Géol. Finlande 191. 49 p.

Tugarinov, A. Il.; Balashov, Yu. A. and Gavrilova, L.K. (1973) Abundances of the rare earth elements in the lower proterozoic Krivoy Rog series. Geochem. Int. 10: $24-29$.

Wildeman, T. R. and Haskin, L. A. (1973) Rare earths in Precambrian sediments. Geochim. Cosmochim. Acta 37: 419-438.

Manuscript received, January 31, 1975. 